\title{
Research on the Ecologism of the Classic Fairy Tales "Rabbit Hill"*
}

\author{
Maixia Guo \\ School of Literature \\ Longdong University \\ Qingyang, China 745000
}

\begin{abstract}
The novel "Rabbit Hill", which won the Newbery Children's Literature Prize, is written by the famous American writer Robert Lawson. The novel tells the excitement of small animals on a hill named Rabbit Hill due to the news of a new family coming here, and the misunderstanding between small animals and the new family. Finally, they lived in harmony. The storyline is easy to understand. However, it contains the author's deep thoughts on the relationship between humans and nature. From the perspective of ecologicalism, this paper excavates the novel by interpreting and analyzing the natural ecological beauty, implicit respect for nature, and the ecological tendency of advocating harmonious coexistence between man and nature. In this paper, we can see the ecological meaning that is not known by the public.
\end{abstract}

Keywords—Rabbit Hill; ecological aesthetic; nature

\section{INTRODUCTION}

In 1945, Robert Lawson won the Goldfield Award for Newbery Children's Literature with the help of "Rabbit Hill". "Rabbit Hill" is a novel based on animals. Human activities occupy a small proportion in the novel. In the whole novel, people are more like a background for animal activities. In this novel, the author intentionally dispels the subject identity of the human being as the master of nature. In this novel, human beings are the members of nature. The author pays close attention to the living conditions of the animal, highlighting the subjectivity of the animal. And this novel pays attention to the display of the animal's inner world. This reflects the good, courageous and just inner beauty of the small animals. The novel promotes the value and survival of animals. It has completed the thinking on the relationship between humans and animals.

\section{THE BEAUTY OF LIFE}

Robert Lawson sketched the beauty of nature without staying in the beauty of the natural external form. However, Robert Lawson projected the observation feelings of nature

*Fund Project: Gansu Provincial Education Science Planning Project: "Ecological Aesthetics and Environmental Protection Education in Classic Fairy Tales" GS[2017]GHBZ044

Scientific Research Project of Gansu Province Higher Education: An Exploration of the Ecological Civilization Consciousness in the Works of Gansu Children's Literature "Eight Horses" (2017A-101)

CLC number: I206.7 Document code: A into the inner beauty of the natural creature, integrating the self and the nature. It is inseparable. In "Rabbit Hill", the author wrote the small animals living on the Rabbit Hill in anthropomorphic way. They are like a small society in order. In Jocky's family, there are rigorous, helpful and prestigious daddy, loving, sorrowful and embarrassed mothers, and married sisters Hazel, who have three children in the coal mountain. They know how to make soup, build storage shelves, and pickle vegetables. Their neighbors are Marmo Poch, Grey Fox, Grey Squirrel, Field Mouse Willie, Mole, Skunk Feiwei, Red Deer, Cutworm, etc... The author describes the survival activities of small animals in the natural state, praises the animal's tenacious vitality and survival wisdom, as well as the true affection between the natural species and the ethnic group. It reflects the complex interdependence between animals and humans.

According to the writing style of Robert Russell, the natural scenery is beautiful. However, he pays more attention to the beauty of life. Rabbits are undoubtedly weak in nature. They have no sharp teeth. And most of them choose to escape in the face of danger. However, the rabbit Jocky in "Rabbit Hill" is brave. When confronted with the hounds of the hunting dogs, he calmly responds and has strategic escape. When he is forced to the river, he struggles and jumps over the wide river. He has made amazing record. In the Qing dynasty, the Hakka painter Hua Qin (Shanghang, Fujian province) created the "Chinese flowering crabapple and Rabbit" in his later years to show the story of a black rabbit pedaling snipe. [1] The docile rabbit broke out in the dangerous moment when snipe attack him. It was so smart and alert. The beauty of life embodied in the rabbit Jocky is equally impressive. In his novel, the rabbit Jocky respects his parents and has love for his elders. It is brave.

\section{THE BEAUTY OF LOVE AND WARMTH}

In the novel, the excellent and beautiful qualities of human beings are fully reflected in the small animals, and they become beautiful creatures similar to human beings. The little animals are compassionate and respectful. The hills are ridiculous because there have no one to live for a long time. The little animals are hungry every day. When the little rabbit Jocky's family relies on drinking soup to maintain their lives, they still do not forget to help old and lonely uncle Anadars, who lives far away from Jocky's family and 
lacks the living food. Also, they propose to pick him up to live at home. They help each other. The rabbits set their own safety, disregarding the wit and chasing the hunting dogs, and saved the foxes being traced. They love each other. The Field Mouse Willie and Mole are good friends. Mole treats Field Mouse Willie as its eyes. Willie also gets the fresh and delicious plant roots that Mole encounters when burrowing. They are full of justice, and dare to love and hate. Although they are small animals, their strength is small. When Willie accidentally falls into the rain bucket, he is rescued by the owner. However, the friends lose the news. Mole is the most angry and sad. He feels that he loses his partner and his own eyes. He is angry, "I'll teach them a lesson." "I'll teach them a lesson." There will never have a grass here - never! There will never have a small tree root here. I will dig up the roots..." [2] After distributing the foods, little Jocky, who was loved by everyone, was hit in the driveway. And the animals became anxious. The fear, doubt, sorrow, and resentment control them. They missed the goodness of little Jocky, imagining the picture of little Jocky being abused by humans. The hatred born of love is filled with small animals. And the relationship between small animals and humans is drawn. Uncle Anadars is angry. "I want to teach them a lesson." Waiting for a rainy day, the road is dark and slippery. I will hide at the corner of the mountain. When they rush over, I will jump in front of them. They will be scared, and they will slam on the brakes. The car will slip into the stone wall next to it. [3] They are the family full of love and warmth everywhere.

\section{THE BEAUTY OF HARMONY}

In the opinion of Han Dexin, from the perspective of ontology, there is oneness relationship between man and nature. It is the unity of man-made nature and the existence of nature. There is a harmonious relationship of symbiosis and common prosperity between man and nature. This relationship is beautiful. [4]"

The little animals on the Rabbit Hill are running around and telling one thing, "There is a new family moving in." They are very happy with this, full of embarrassment and eagerness. They hope that the new family is farmer. The old daddy believes, "there are several households in the vicinity, we have a good life." The field mouse Willie believes that if there are new people, there may have seeds. The seeds and chicken fall from the cracks. They can enjoy them all winter." [5] Red Deer hopes to eat lettuce and tender cauliflower in the vegetable garden. The skunk Feiwei is eager to eat leftovers. The spring has not yet arrived. For the small animals on the desolate hill, the news of new family is a new hope. For small animals who survive relying on human, the hills without people are too bleak and barren. The life becomes extremely difficult. The rabbit Jocky's family can only rely on the porridge. At the same time, the small animals are worried. They also worry that the new people will endanger their safety. Jocky's mother thinks of dogs, cats, shotguns, explosives, rat poison baits, poison gas, and little boys, and gradually becomes restless. The arrival of the new family is not only the gospel of the animals, but also the expectations of the residents around the hill. Carpenters, plasterers, grocery store owners and small animals are singing the same song. "The new family is coming." They want the new family to bring them new job opportunities.

"Mure believes that there is interdependence relationship between various living things, just like birds can't live without streams, streams can't be separated from birds. And grace is connected with wilderness. The soft exists with the power. "[6] There are relationships of co-existence and common prosperity between humans and small animals. When no one lives on the hill, the hills are desolate. Small animals can't find food to eat. When humans stay, there will be a series of problems. For example, human-raised cats and dogs will endanger the safety of small animals. The walls and lanes people build will hinder the travel of small animals For example, a fast-moving car accidentally injured little Jocky. The mother's most beloved little grandson, Sloan Morton, was killed by a truck. The skunk who likes to eat leftovers hopes that the owner doesn't use a new type of trash which can be buried in the underground with iron cover, but a trash with a loose lid. Here, with the mouth of small animals, the ecological positive meaning of garbage classification is also stated. Human waste doesn't refer to mixing fresh leftovers with moldy garbage and lead cans. It is of great significance to small animals that survive relying on garbage. Human beings are not the only creatures of the earth. There are many small animals that depend on human survival.

\section{REFLECTIONS ON THE RELATIONSHIP AMONG HUMANS AND ANIMALS AND NATURE}

In the "Rabbit Hill", the rabbit had got along with many people before. And their attitudes toward rabbits and small animals were different. There was a period of prosperity and a difficult period of survival. The new owner is an ideal neighbor in the heart of a small animal. He is kind and compassionate. In order to avoid harming small animals, a signboard is placed at the entrance of the driveway. "Please look at the small animals and drive carefully." He rescued the field mouse Willie who fell into the rain bucket and took care of him. His wife saved the groundhog Pouch from the dog's mouth, and passed the test of the rabbit's old father and the gray fox.

The plasterer Louis Doke approached the hole of the marmot when helping the new owner build a new stone wall. The new owner gave up the wall for the groundhog, causing the shock of the plasterer Louis Doke. The new owner disagreed with Louis Doke's suggestion to eliminate the groundhog and the mole with a gun and a rat clip, and his wife also gave up the suggestion that Tim Mark Grasse built a fence around the garden. In the eyes of the plasterers Louis Doke and Tim Mark Grasse, this is a strange family. They believe that people of this family are "good guys".

This family loves animals and tries their best to help small animals. It provides abundant food for small animals during the midsummer night harvest. The statue of Saint San Francesco di Assisi, which cares for small animals, is built on the open space. They provide various foods that the animals love to eat around the statue, clean drinking water 
for the small animals. And then, these animals can have rich food to go throughout the summer. However, they quietly leave. Humans are grateful for the gift of nature. At the same time, human beings spread love to nature. Small animals are also grateful for the gift of the owner. They will not damage the garden before the vegetables is ripe, and take the initiative to take care of the garden. These animals have clear division of labor, guarding the harvest of the vegetable garden. The harmonious coexistence of humans and animals has won good results.

The existence of human beings has negative impact on nature. However, it also has positive impact. The author doesn't have pessimistic attitude of anti-ecologicalism in this article. With the relationship of the interdependence between humans and animals on the hill, it points out the positive role of people in the entire ecosystem. Without people, the hills are absurd and barren. Human participation has brought about fruitful results, and small animals have benefited from it.

\section{EVERYTHING IS EQUAL}

In the "Introduction to Ecological Aesthetics", Mr. Zeng Fanren has mentioned that everything is equal, and there is no distinction between lowliness and nobleness. [7] The disagreement between the family and the plasterers Louis Doke and Tim Mark Grass on whether to eliminate the groundhog and the mole, and whether to build a garden fence is actually the different world view. Louis Doke and Tim Markgras are typical anthropocentrists. Their criteria for judging small animals are harmful to human interests. If they are harmed, the small animals are regarded as hostile objects. Human beings should use human violence to deal with small animals, regardless of the survival requirements of weak animals. This family regards small animals as friends of human beings. Everything is equal. Small animals also have the right to enjoy natural gifts and survival. Human beings should coexist with the small animals peacefully. For example, the novel author states that the male owner takes the initiative to take off his hat to say hello to the rabbit passing by the car and greet the fox appearing in the field of vision. When building the wall, the owner intentionally avoids the home of the groundhog Pouch.

"The small animals also send the field mouse Willie to watch the life of the family. They don't peep at the family maliciously. In the hearts of small animals, the hills are not only the hills of humans, but also the hills of small animals." The work breaks through the constraints of anthropocentrism and regards animals as the members of nature. It has advanced ecological significance.

Ecological literature emphasizes people's responsibility and obligation to nature. It calls for people to love nature, praise nature, protect nature, and maintain ecological balance. At the same time, it advocates reflection and criticism of human madness in natural control, conquest and incontinence to treat natural creatures with the spirit of Christian love [8]. As the end of the article, the plasterer Louis Doke and the tractor-driven Tim Mark Grasse has a meaningful dialogue. Tim Mark Grasse does all the defenses such as "fences, rat clips and bait". Even in a few nights, he takes a gun to safeguard the vegetable garden. However, his garden suffers a lot of damage, and the carrots are gone. The beets are lost, and the cabbages are bitten. The tomato is trampled, and the grass is ruined. The man who kept the dog at the crossroads did not leave a corn. All the lettuce and most of the turnips were reimbursed. Tim Mark Grasse suggested that the new owner set the mouse clip. They express the disdainful opinion on the owner's tolerance, ridiculously saying "foolish readers". He does not understand why the vegetables of this family are in good condition without any precautions. Finally, they believe that this family is lucky. Louis Doke thinks more about "may be like this -and there may have other factors as well. The unexplained discourse is a sign of anthropocentrism's rethinking of the relationship between man and nature.

\section{CONCLUSION}

Robert Lawson is a famous writer in the United States. His children's literature "Rabbit Hill" is based on the small things of small animals. The plot structure is simple. However, the ideas displayed in the works do cause people's reflection. In the Catholic spirit, human beings are the master of nature, and human beings dominate all things in nature. The most harmonious relationship between man and nature is the kindness and benevolence of all things. The starting point for judging the right and wrong is anthropocentrism. For example, the harmonious and beautiful realm finally revealed in the novel is that the animals enjoy the food of human love around the statue of San Francesco di Assisi, which symbolizes the spirit of nature. The novel is not confined to the framework of anthropocentrism. It is made by the mouth of the animal. For example, the human beings pay tribute to the animals in the book. When the wall is built, human beings circumvent the animal's lair. When the animals madly revenge the human beings, people will fear the nature. Through the mouth of the small animal, "the hill is not only a hill of human beings, but also a hill of animals". The novel pays attention to the relationship between man and the ecological environment. In the novel, the small animal and human beings sing the words "new people are coming". They sing the same melody and look forward to the arrival of new life. This new life is the common prosperity of humans and animals. The beautiful and prosperous world of ecological harmony is like a prophecy, and it seems to be a bright future.

\section{REFERENCES}

[1] Wu Meizhen. Rabbit image in the classic fairy tale and aesthetic analysis [D]. Master's Thesis of Anhui University, 2011:23-23.

[2] Robert Lawson. Rabbit Hill [M]. New Buds Publishing House, 2011::80-81.

[3] Robert Lawson. Rabbit Hill [M]. New Buds Publishing House, 2011::95.

[4] Han Dexin. Possibility of Literature Research in Ecological Methods [J]. Shandong Social Sciences, 2005 (11)): 60-63.

[5] Robert Lawson. Rabbit Hill [M]. New Buds Publishing House, 2011::10. 
[6] Chen Yanyan. Aesthetics goes to the wilderness--John Mure's ecological aesthetic thinking [D]. Master's thesis of Guangxi University for Nationalities. 2011:32

[7] Zeng Fanren. Introduction to Ecological Aesthetics [M]. Beijing: The Commercial Press, 2010: 156

[8] Zhang Yanxia. Research on the Ecological Aesthetics of Kenji Miyazawa's Fairy Tales[D]. Master's Thesis of Zhejiang Normal University. 2012:25-26 